\title{
Benlik Farklılıklarına Rogers'ın Danışan Odaklı \\ Terapisi ile Yaklaşım: Vaka Çalışması
}

\author{
Derya Gürcan \\ Orta Doğu Teknik Üniversitesi
}

\begin{abstract}
Özet
Bireylerin benlikleri arasında yaşadıkları fark uzun zamandır psikoloji biliminin gündeminde olmuştur. Carl Rogers'ın teorisi de dahil olmak üzere, teoriler genellikle gerçek benlik ile ideal benlik arasındaki farka odaklanmışlardır. Ancak Higgins, bireylerin üç farklı benlik kavramının olduğunu öne sürmüştür. Bunlar gerçek benlik, ideal benlik ve zaruri benliktir. Higgins, ayrıca kişinin kendi bakış açısının ya da kendisi için önemli birinin bakış açısının da benlik kavramının oluşumunda etkili olduğunu belirtmiştir. Higgins farklılıklar karşısında bireyin farklı olumsuz duygular yaşadığını öne sürmüştür. Rogers ise benlik farklılıklarının bireylerin çocuklukta koşulsuz olumlu kabul alamamaları sebebiyle oluştuğunu ve bireyin yaşadığı olumsuz duygularla savunma mekanizmaları yardımıyla başettiğini söylemiştir. Rogers benliğin gelişiminin çocukluk dönemi ile sınırlı olmadığına inandığı için, terapi ortamında danışan gerçek, samimi, empatik ve koşulsuz olumlu kabulü yaşayabildiği bir ilişki deneyimleyebilirse, benlik temsilleri arasındaki farkın azalacağını ve kişinin kendini gerçekleştirme yönünde ilerleyebileceğini belirtmiştir. Bu makalede, benlik farklılıkları ve Rogers'ın danışan odaklı teorisi derlenmiş, benlik farklılığı yaşayan bir danışan ile örneklendirilmiştir.
\end{abstract}

Anahtar Kelimeler: Benlik farklılıkları, Carl Rogers, Danışan Odaklı Terapi. 


\section{Benlik Farklılıklarına Rogers'ın Danışan Odaklı Terapisi ile Yaklaşım: Vaka Çalışması}

\section{Benlik Farklılıkları}

Bireylerin benlik temsilleri arasında yaşadıkları fark psikoloji biliminde uzun yıllardır araştırma ve teori gündeminde olmuş; kişilerin bu farklılık sebebiyle yaşadıkları rahatsızlıklar teorisyen ve araştırmacıların odağı olmuştur (Higgins, 1987). Benlik farklılıklarının kökeni Lecky'nin benlik tutarlılığı teorisine kadar uzanmaktadır (Lecky, 1945; aktaran, Stevens, 1992). Lecky'e göre bireyler kişilik yapılarını ve değer sistemlerini doğumlarından itibaren oluşturmaya ve geliştirmeye başlar, oluşturdukları benlik temsillerine göre davranırlar. Lecky, bireylerin yaşamdaki temel motivasyonlarının bütünlük için çaba harcamak olduğunu söylemiştir. Eğer birey bu bütünlük ile uyumsuz olarak davranırsa, bunun yarattığı olumsuz duygu ile savunma mekanizmaları ile başedecektir. Bireyin savunma mekanizmaları ile başedemediği durumlar ise psikopatolojiye sebep olabilmektedir (Lecky, 1945; aktaran, Stevens, 1992). Carl Rogers Lecky'nin teorisinden etkilenmiş ve bireyin iyilik halinin benlik temsili ile yaşantıları arasındaki uyum ve tutarlılık ile ilişkili olduğunu öne sürmüştür (Feist ve Feist, 2008). Benlik ve yaşantı arasındaki uyumun yanısıra, Rogers ayrıca benliğin, ideal benlik ve gerçek benlik olmak üzere iki ayrı yapısının olduğunu söylemiş, ideal benlik ile gerçek benlik birbiri ile uyumlu ise bireyin sağlıklı ve uyumlı olduğunu, ancak aralarında farklılık var ise bireyin anksiyete, depresyon ve özgüven eksikliği yaşayacağını belirtmiştir (Feist ve Feist, 2008).

1980'lerde Tory Higgins ise Rogers'ın benlik hakkında söylediklerini, benlik farklılıkları teorisi adı altında geliştirmiştir. Higgins'in teorisinde Rogers'ın teorisinden farklı olarak üç farklı benlik temsili vardır. Bunlar gerçek benlik, ideal benlik ve zaruri benliktir (ought self). Higgins'e göre gerçek benlik bireyin gerçekte sahip olduğuna inandığı özelliklerdir. İdeal benlik kişinin ideal olarak sahip olmayı istediği özellikleri temsil ederken (ör. umut ve istekler), zaruri benlik ise bireyin sahip olmasının zorunlu ya da gerekli olduğuna inandığı özellikleri temsil etmektedir (ör. görev ve sorumluluklar) (1987).

Higgins benlik farklılıklarını anlamada sadece benlik temsillerini ayırt etmenin yeterli olmadığını savunmuştur. Benlik temsillerinin oluşmasında kimin bakış açısının etkili olduğunun da teoriye eklenmesi gerektiğini düşünmüştür. Higgins benlik üzerinde etkili iki bakış açısı olabileceğini ileri sürmüştür. Bunlar kişinin kendisinin ya da hayatındaki önemli birinin (ör. anne, baba, eş gibi) bakış açılarıdır. Benliğe bakış açılarının eklenmesi ile birlikte teori altı farklı benlik temsili ortaya koymuştur: gerçek/kendisi, gerçek/başkası, ideal/kendisi, ideal/başkası, zaruri/kendisi, zaruri/başkası. Bu benlik temsillerinden ilk ikisi benlik kavramını, diğer dördü ise benlik rehberini (self-guide) oluşturmaktadır (Higgins, 1987). Teori bireylerin değişik benlik temsillerini aynı anda kullanıyor olabileceğini, bir bireyin tüm temsilleri kullanmasının ise beklenmediğini önermektedir. Örneğin, bir bireyin hayatında zaruri/başkası benlik temsili en çok etkiye sahip iken, bir diğerinin hayatında ideal/kendisi benlik temsili en çok etkili olabilir (Strauman ve Higgins, 1988). Benlik farklılıkları teorisi, bireylerin benlik kavramı ile benlik rehberleri arasında bir dengeye ulaşma motivasyonuna sahip olduklarını önermektedir (Strauman ve Higgins, 1988). Benlik farklılıkları teorisinin daha önceki teorilerden farklı olarak öne sürdüğü bir diğer argüman ise, farklı temsiller arasındaki farkların, değişik hassasiyet ve duygulara sebep 
olacağıdır. Teori, gerçek benlik ve ideal benlik arasındaki farkların hoşnutsuzluk, mutsuzluk, hayal kırıklığı gibi üzüntü ile ilgili duygular yaratacağını, gerçek benlik ile zaruri benlik arasındaki farklılıkların ise korku, tehdit, sinirlilik gibi ajitasyon ile ilgili duygular yaratacağını öne sürmektedir (Strauman ve Higgins, 1988). Daha ayrıntılı bakılacak olursa, birey gerçek/kendisi benlik temsili ile ideal/kendisi benlik temsili arasında farklılık yaşadığında kişinin kendisi ile ilgili gerçek inançları, ideal benliği ile uyuşmazlık gösterecektir. Teoriye göre, bu farklılığı yaşayan bireyin umut ve isteklerini gerçekleştirememiş olması, dolayısıyla hayal kırıklığı, hüsran ve mutsuzluk yaşaması beklenmektedir. Eğer gerçek/kendisi benlik temsili ile ideal/başkası benlik temsili arasındaki fark kişinin yaşantısında baskın ise birey kendisi için önemli olan birinin kendisi ile ilgili umut ve isteklerini yerine getirmede başarısızlık yaşamış olduğunu düşünecek ve bu başarısızlık bireyde utanç ve mahcubiyet duygularına sebep olacaktır (Higgins, 1987). Bir diğer farklılık gerçek/kendisi ile zaruri/başkası benlik temsilleri arasındadır. Eğer kişi bu farklılığı yaşarsa, kendi benliği ile ilgili inançları ile kendisi için önemli olan birinin kendisinden, görev ve sorumluluk olarak beklentileri arasında uyumsuzluk yaşayacaktır. Bu uyumsuzluk sebebiyle kişi korku, tehdit edilmişlik hissi ve kızgınlık yaşayacaktır (Higgins, 1987). Higgins'in öne sürdüğü son farklılık gerçek/kendisi benlik temsili ile zaruri/kendisi temsili arasındadır. Kişi bu farklılı̆̆ yaşadığında kendisi ile ilgili sahip olduğu inanç ile kendisinden beklediği sorumluluklar arasında farkl11ık deneyimleyecektir. Bu farklılık sebebi ile kişi suçluluk, kendinden nefret etme, tedirginlik, ahlaki değersizlik gibi hisler yaşayacaktır (Higgins, 1987). Günümüzde yapılan çalışmalara bakıldığında, Higgins'in değişik benlik farklılıklarında, ayrı duygular yaşayacağı hipotezi ile ilgili çelişkili sonuçlar bulunmaktadır (Stevens, Lovejoy ve Pittman, 2014).

Araştırmaların büyük çoğunluğu gerçek/ideal benlik farklılığının depresif duygularla ilişkili olduğunu göstermekte, fakat gerçek/zaruri benlik farklılığının kaygı ile bağlantılı olduğu çalışmaların bir kısmında kanıtlanabilmektedir (Stevens, Lovejoy ve Pittman, 2014).

Benlik farklılıkları teorisi, benlik temsilleri arasındaki fark ne kadar büyükse ve kişi sayı olarak ne kadar çok farklılık yaşıyorsa, benlik farklılığının o kadar çok olacağını söylemiştir. Ayrıca, benlik farklılığı ne kadar çok ise kişinin yaşayacağı rahatsılı̆̆ı̆ın da o derecede yoğun olacağını belirtmiştir (Higgins, 1987). Higgins kişinin yaşadığı farklılık ile ilgili farkındalığının olmayabileceğini de eklemiş, farklılığın bireyi otomatik olarak ve farkındalık dışında da etkileyebileceğini vurgulamıştır (1987). Son olarak, özgüvenin ideal benlik ve gerçek benlik arasındaki farklılık ya da tutarlılıkla ilgili olduğunu, bireyin yaşadığı farklılık çok ise özgüveni düşük, farklılığı az ise özgüveninin daha yüksek olacağını öne sürmüştür (Cervone ve Pervin, 2008). Barnett ve Womack'ın (2015) yaptıkları çalışmada gerçek benlik ile ideal benlik arasındaki farkın özgüven eksikliği ile anlamlı olarak ilişkili olduğu, fakat özgüvenin gerçek/zaruri benlik farklılığı ile ilişkisinin olmadığı bulunmuştur. Bu bulgular, Higgins ve Rogers'ın önerileri ile aynı doğrultudadır (Barnett ve Womack, 2015).

Bu makalede Benlik Farklılıkları teorisi, Rogers'ın Danışan Merkezli yaklaşımı ile birlikte ele alınacaktır. Ayrıca benlik farklılıkları yaşayan Bayan E. vakası ile örneklendirilecektir.

"Bayan E. 19 yaşında bir üniversite öğrencisidir. Kliniğimize kararsızlık şikayetleri ve "Kim olduğumu bilmiyorum, ne istediğimi ve ne yapmak istediğimi bilmiyorum" "Kendimi bulmak ve tanımak istiyorum” diyerek başvurmuştur. Bayan E.'nin kararsızlık ile ilgili şikayetleri detaylandırıldığında, hayatının her alanında kararsızlık yaşadığını ve bunun kendisini yorduğunu anlatmıştır. Kıyafet seçimi, yapacağı ödev için konu seçimi, ders seçimi ve bunlar gibi birçok konuda kararsızlık yaşadığını, kendi kararlarına bir türlü güvenemediğini bu sebeple de sürekli etrafındaki insanların fikirlerini sorduğunu belirtmiştir. Kendisi karar veremediği ve sürekli etrafındakilere fikir sorduğu için de kendisini çok özgüvensiz hissettiğini eklemiştir. Bayan E.'nin yaşam öyküsüne bakıldığında, küçük bir kasabada doğup büyümüş ve üniversiteyi kazanana dek 
ailesiyle birlikte kasabada yaşadığını belirtmiştir. Bayan E. ailesinin ataerkil ve dindar bir aile olduğunu, bu sebeple evlerinde sadece erkeklerin sözünün geçtiğini, kadınların görevinin hizmet etmek ve erkeklerin söylediklerini yapmak olduğunu anlatmış, dindar bir aile oldukları için başörtüsü örttüğünü eklemiştir. Bayan E. böyle bir ortamda yetişmesinin ardından üniversiteyi kazanarak ailesinden ayrıldığı belirtmiştir. Üniversitede, kendi aile yapısından çok farklı bir ortamla karşılaşan Bayan E. karmaşa yaşadığını, kendisinin hangi dünyaya ait olduğunu bilmediğini ifade etmiştir. Üniversite hayatını yaşadıkça, kendisini bu dünyaya ait hissetmeye başladığını, bir müddet sonra başörtüsü takmamaya, ailesinin tasvip etmeyeceğini bildiği şeyleri kendisi ilgi duyduğu için yapmaya başladığını söylemiştir (ör. voleybol, eşli danslar vb.). Bayan E. kendisini bu şekilde daha mutlu hissettiğini söylese de, ne zaman ailesinin yanına gitse suçluluk hissettiğini, onlara ihanet ediyormuş gibi olduğunu anlatmıştır. Bayan E. aile ve okul yaşantılarını göz önünde bulundurduğunda hangisinin doğru, hangisinin yanlış olduğunu bulamadığını, bu sebeple kendisini üzgün ve suçlu hissettiğini ifade etmiştir. Bunun dışında Bayan E. günlük yaşantısında, her giriştiği işte başarılı olmayı ve çevresindekiler tarafından başarılarının takdir edilmesini istediğini anlatmıştır. Ayrıca girdiği ortamlarda sözü dinlenen ve öne çıkan biri olmayı dilediğini eklemiştir. Ancak bunların bir kısmını gerçekleştirebilmekte, gerçekleştiremediğinde ise üzüntü duyduğunu anlatmaktadır.

Benlik farklılıkları teorisine göre ele alındığında, Bayan E.'nin gerçek benlik/kendisi ile ideal benlik/kendisi ve zaruri benlik/başkası ile zaruri benlik/kendisi benlik temsilleri arasında farklılıkları olduğu düşünülmektedir. Gerçek benlik/kendisi ve ideal benlik/kendisi temsilleri arasındaki farka bakıldığında, Bayan E.'nin giriştiği her işte başarılı olma ve bunun takdirini alma istediğinin olması, içerisinde bulunduğu ortamlarda sözü dinlenen, lider pozisyondaki kişi olmak istemesi gibi ideal benlik/kendisi'nden gelen istek ve umutlara sahip olduğu görülmüştür. Ancak gerçek benlik/kendisi'nin bu beklentileri her zaman karşılayamadığ 1 ve bu farklılık sebebiyle Bayan E.'nin mutsuzluk ve hayal kırıklığg yaşadığı izlenimi edinilmiştir. Bayan E.'nin gerçek benlik/kendisi, zaruri benlik/başkaları temsilleri arasında da ciddi bir farkın olduğu görülmüştür. Ailesinin kendisinden görev ve yükümlülük olarak, kapalı olması, dini görevlerini yerine getirmesi, ders çalışmak dışında aktivitelerinin olmaması, erkek arkadaşının olmaması, hatta erkeklerle gerekmedikçe sohbet etmemesi gibi beklentilerinin olduğu görülmüş̧ür. Ancak Bayan E. süreç içerisinde, başörtüsünü çıkarmış, birçok topluluğa aktif olarak katılmış, erkek arkadaş edinmiştir. Bunları ailesinden gizleyen Bayan E.'nin, ailesinin kendisinden zorunluluk olarak bekledikleri ve kendisinin gerçek benliği arasındaki bu ciddi fark sebebiyle, köye ailesinin yanına gitmesi gerektiği zaman onların bunları öğreneceğinden korktuğu ve yanlarına gitmek istemediği görülmüştür. Bayan E.'nin yaşadığı düşünülen son benlik temsili farklılığ1, gerçek benlik/kendisi ve zaruri benlik/kendisi arasında olduğu düşünülmüştür. Ailesinin kendisinden bekledikleri kadar çok olmasa da Bayan E.'nin zaruri benlik/kendisi temsili ile gerçek benliği arasında da farklılıklar vardır. Erkek arkadaşının olması ve onunla yakınlaşması, dini gereklilikleri yerine getirmemesi gibi konular Bayan E. için yapılmaması gereken şeylerdir. Fakat, Bayan E. gerçekte erkek arkadaşı ile yakınlaştığında haz aldığı için onunla yakınlaşmakta, günlük yaşantısında zaman ayırmadığı için de dini gereklilikleri yerine getirmemektedir. Böylece Bayan E. zaruri benliğine ait görev ve sorumlulukları yerine getirememekte ve bu su sebeple yoğun suçluluk hissettiğini söylemektedir.

Bayan E.'nin birçok benlik temsilinde farklılık yaşaması, özellikle de gerçek benlik/kendisi ve zaruri benlik/başkası benlik temsilleri arasında büyük bir fark olması, benlik farklılığının boyutunun yüksek olduğuna işaret etmektedir. Bu sebeple de Bayan E.'nin farkl111klar nedeniyle yaşadığı sıkıntıların boyutunun yüksek olduğu gözlemlenmiştir." 


\section{Rogers'ın Danışan (İnsan) Odaklı Terapisi Teorinin Başlıca Kavramları}

Carl R. Rogers'ın kişilik teorisi hümanistik bir teoridir. Bu sebeple özgür irade, seçim ve kişisel sorumluluk teorinin özünü oluşturmaktadır. Teori benlik, benliğin özellikleri gibi konuları vurgulamaktadır (Geiwitz, 1969). Teori "eğer-ise" çerçevesi üzerine kurulmuştur. Bu demektir ki, "Eğer belirli koşulları oluşur ise süreç gelişecektir. Eğer süreç gerçekleşir ise belirli kişilik ve davranış değişimleri oluşacaktır." (Geiwitz, 1969; Feist, 2008).

Rogers'a göre, bireyler dış dünyayı algılar, deneyimler ve anlam yüklerler. Tüm bu anlamlandırmalar birey tarafından "ben" olarak algılanır. Rogers, benlik kavramını bu algı ve anlamlandırmaların, düzenli ve tutarlı hali olarak açıklamıştır (Cervone ve Pervin, 2008). Rogers, benlik kavramı oluştuktan sonra, bireylerin değişimi ve yeni öğrenmeleri zor bulduklarını ancak bunun imkansız olmadığını savunmuştur. Benliğin, bir süreç, değişim ve akışkan olduğunu, her zaman psikolojik büyümeye doğru ilerleyebileceğini eklemiştir (Frager ve Fadiman, 1998). Rogers, kişinin farkındalığının dışında deneyimleri olabileceğini ancak insanların genel olarak farkında ve bilinçli olduklarını öne sürmüştür (Feist ve Feist, 2008). Bunların dışında, Rogers ideal benlikten bahsetmiştir. İdeal benliğin, benliğin alt kümesi olduğunu ve bireyin olmak istediği benlik olduğunu söylemiştir (Feist ve Feist, 2008). Benlik gibi, ideal benliğin de akışkan ve değişebilir bir yapısının olduğunu belirtmiştir (Frager ve Fadiman, 1998). Rogers ideal benliğin, bireyin ulaşmaya çabaladığı bir model olduğunu, ancak ideal benlik ile benlik arasında büyük bir fark olduğunda bireyin rahatsızlık yaşayacağını ve bu durumda ideal benliğin bireyin gelişimini engelleyeceğini öne sürmüştür (Frager ve Fadiman, 1998).

Rogers insanların daima gelişebilme, ileriye gidebilme potensiyelinin olduğuna inanmış ve bunu kendini gerçekleştirme eğilimi olarak adlandırmıştır (Schultz ve Schultz, 2005; Feist ve Feist, 2008). Kendini gerçekleştirme eğilimi gelişme, olgunlaşma, özerk olma, bütün olma ve psikolojik ve fiziksel olarak kendini gerçekleştirmeyi içermektedir (Schultz ve Schultz, 2005; Frager ve Fadiman, 1998). Kendini gerçekleştirme eğilimi bireyi geliştiren tatmin ve hazzı vurgulasa da, ihtiyaçları karşılayarak ve benlik kavramını korumaya çalışarak, dengede olabilmeyi de içermektedir (Cervone ve Pervin, 2008). Rogers kendini gerçekleştirme eğiliminin sadece belirli koşullar gerçekleştiğinde oluşabildiğini belirtmiştir. Bu koşullar; bireyin, kendisi için önemli bir kişi ile olan ilişkisinde, içtenlik (samimiyet), empati, koşulsuz olumlu kabul alabiliyor olmasıdır. Bu koşullar sağlandığında kişi doğuştan gelen kendini gerçekleştirme eğilimini olumlu bir şekilde tamamlayabilmektedir (Feist ve Feist, 2008).

Yaşam sadece olumlu yaşantıları ve kendini gerçekleştirmeyi içermemekte, çatışma, şüphe, stres gibi olumsuzlukları da içermektedir. Bu durumda kendini gerçekleştirme, benliği açıklamak için yetersiz kalmaktadır. Rogers bu durum için bireylerin yaşamlarında, benlik ve tecrübeleri arasında uygunluk (congruency) ve tutarlılık (consistency) aradıklarını belirtmiştir (Cervone ve Pervin, 2008). Uygunluğun benlik ile deneyim arasındaki tutarlılık olduğunu, eğer farklılık yaşanırsa bireyin uyuşmazlık (incongruence) yaşayacağını öne sürmüştür (Frager ve Fadiman, 1998).

\section{Benliğin Gelişimi}

Daha önce de belirtildiği üzere, çocuklar benliklerini dış dünyayı algılayarak, deneyimleyerek ve bunlara anlam yükleyerek benliklerini oluştururlar. Benliklerinin farkında olmaya başladıktan sonra neyin iyi ya da kötü, haz veren ya da vermeyen şeyler olduğunu öğrenirler (Feist ve Feist, 2008). İlkel benlik yapılarını oluşturduktan sonra, kendini gerçekleştirme eğilimleri (actualizing tendency) oluşmaya başlar. Kendini gerçekleştirme eğilimi 
oluştuktan sonra, Rogers'a göre gelişim sadece çocukluk yılları ile sınırlı kalmamakta, birey ömrü boyunca kendini gerçekleştirmek için çabalamaktadır (Feist ve Feist, 2008). Rogers'a göre, çocuk (ya da yetişkin) başka bir bireyden kabul algıladıktan sonra, olumlu kabule değer vermeye, olumsuz kabulü ise değersizleştirmeye başlamaktadır. Bunun ardından çocuk sevilme, kabul edilme, saygı duyulma ihtiyaçlarını geliştirmeye başlamaktadır. Rogers bunu "olumlu kabul" olarak adlandırmıştır. Çocuğun sevilme, korunma, kabul edilme ihtiyaçlarının ailesi ya da bakım veren kişi tarafından koşulsuz olarak verilmesi gerektiğine inanmış, bu kavramı ise koşulsuz olumlu kabul olarak adlandırmıştır (Feist ve Feist, 2008; Burger, 2011). Rogers ayrıca olumlu kendini kabul (positive self regard) kavramından bahsetmiştir. Olumlu kendini kabulü kişinin kendi benliğini takdir etmesi ve değer vermesi olarak tanımlamıştır. Kişinin kendisine olumlu kabul verebilmesi için ise bireyin öncelikle başkalarından koşulsuz olumlu kabul alabilmesi gerektiğini belirtmiştir. Ayrıca, kişinin, koşulsuz olumlu kabulü alıp, olumlu kendini kabulu gerçekleştirebildiğinde, daha sonraki yaşantısında başkalarına gereksinim duymadan, özerk olarak kendisine kabul verebildiğini eklemiştir (Feist ve Feist, 2008). Olumlu kabulun bir diğer önemli özelliği ise doğası gereği karşılıklı olmasıdır. Bu demektir ki, birey başkasının olumlu kabul ihtiyacını karşıladığını hissettiğinde, kendisinde de bu ihtiyacın karşılandığına dair doyum hissetmektedir (Schultz ve Schultz, 2005). Birçok çalışma, kabul edici ve demokratik aile ortamının, çocuğun psikolojik gelişimini ve özgüvenini olumlu etkilediğini söylemektedir. Bu demek oluyor ki koşulsuz olumlu kabul ihtiyacı benlik oluşumunun merkezinde yer almaktadır.

Ancak, genellikle aileler çocuklarına koşulsuz olumlu kabul vermeyi tam olarak başaramamaktadırlar. Eğer aileler çocuklarına onları sevdiklerini sadece belli şartlar oluştuğunda, örneğin çocuk bir konuda başarılı olduğunda gösterirlerse, bu durumda çocuk sadece bu koşullarda sevilmeye değer olduğunu hissedecektir. Rogers, bunu "değerli olmanın koşulları" (conditions of worth) olarak adlandırmıştır (Cervone ve Pervin, 2008). Eğer çocuk sadece belirli durumlarda değerli olduğunu hissederse, kendi değerlendirmelerini bırakacak ve sadece ailesi tarafindan kabul gören durumları kendi kişiliğine katacak, bundan sonra bu kriterlere göre davranmaya başlayacaktır (Feist ve Feist, 2008). Çocuk diğerlerinin değerlerini almaya başladığında, değerli olmanın koşullarını kabul etmiş olacak, başkalarının değerlendirmelerine göre yaşamaya başlayacak ve kendi deneyimlerine göre davranmayı bırakacaktır (Schultz ve Schultz, 2005; Feist ve Feist, 2008). Çocuklukta karşılaşılan değerli olmanın koşulları, bireyin kendi benliği ile uyumlu olmayan bir sahte benlik (false self) geliştirmesine neden olacaktır (Feist ve Feist, 2008). Sonuç olarak çocuk uyuşmazlık yaşayacaktır. Benlik ile deneyim arasındaki bu uyuşmazlık ise davranışların uyumsuz ve tutarsız olması ile ortaya çıkacaktır. Rogers'a göre benlik ile deneyim arasındaki fark ne kadar büyük ise kişi o kadar hassas ve zayıf olacaktır (Rogers, 1957; aktaran, Feist ve Feist, 2008). Ayrıca, çocuk bakım ve kabulü ailesinden koşullu olarak aldığında oluşan uyuşmazlık sonucu, deneyimlerini kabul edemediği için savunma mekanizmalarını sıkça kullanan bir yapısı olacaktır. Rogers'ın bu konu ile ilgili değindiği diğer bir önemli nokta ise ilişkiler ile ilgilidir. Gelişimin sadece çocukluk yıllarına ait olmadığını, süreğen bir kavram olduğunu belirten Rogers, eğer erken dönem yaşantılarda çocuk kabul edici ve uyumlu bir aile ortamı yaşayamadı ise, ileriki ilişkilerinde düzeltici deneyimler yaşayabileceğini belirtmiştir (Frager ve Fadiman, 1998).

\section{Psikopatoloji}

Rogers'ın teorisi hümanistik bir teori olması sebebiyle, medikal modeli reddetmektedir. Bu sebeple farklı psikopatolojiler arasında ayırım yapmamıştır. Rogers'ın psikopatoloji ile ilgili tek odağı benlik ve deneyim arasındaki uyuşmazlık ve bireyin gerçekliği inkar ve çarpıtma savunma mekanizmaları ile kabul edememesi üzerine olmuştur. Rogers’a göre uyumsuzluk benlik ile 
deneyim arasındaki en ufak farklılıktan, en uç farklılığa giebilen bir sürekliliktir (Frager ve Fadiman, 1998).

Rogers, bireylerin uygunluğu her zaman yaşayamayacağını, uyuşmazlık ile her karşılaştıklarında depresif ya da kaygılı hissedeceklerini, bu negatif duygularla başedebilmek ve tutarlı ve bütünleşik benliği devam ettirebilmek için savunma mekanizmaları ile başedeceklerini ileri sürmüştür (Cervone ve Pervin, 2008; Burger, 2011). Rogers bireylerin en çok çarpitma ve inkar savunma mekanizmalarını kullandıklarını söylemiştir. İnkarda, bireyin farkındalık düzeyine çıkmaması için deneyimi aktif bir şekilde inkar ettiğini, çarpıtmada ise deneyimi farkındalık düzeyine getirebildiğini ancak gerçekliği benlik ile uyumlu olan bir forma getirecek şekilde çarpıttığını belirtmiştir. Rogers çarpıtmanın, inkar savunma mekanizmasına göre daha sık kullanıldığını, çünkü bir çok deneyimin benliğe uygun şekilde yeniden şekillendirilebileceğini söylemiştir. Rogers ayrıca bir deneyimin inkar ya da çarpıtma savunma mekanizmalarına maruz kalması için sadece olumsuz olması gerekmediğini, bireyin benliği ile uyumsuz olduğunda olumlu deneyimleri de inkar edebileceğini ya da çarpıtabileceğini iddia etmiştir (Feist ve Feist, 2008).

Rogers her bireyin benliği ve deneyimleri arasında belli bir miktar uyuşmazlık yaşadığını, ancak nevrotik bireylerin benlik ile deneyimleri arasında büyük bir fark olduğunu belirtmiştir. Ayrıca, savunma mekanizmalarının kullanımının bu bireylerde sağlıklı bireylere göre daha sık ve daha yoğun bir şekilde olduğunu, deneyimlerinin çoğunun farkındalığa çıkamadığını söylemiştir. Benlik ile deneyim arasındaki uyuşmazlığın çok belirgin olduğu, ya da çok ani bir şekilde oluşup inkar ve çarpıtma mekanizmalarına uğrayamadığı durumlarda ise dağınıklık (disorganization) yaşanayacağını ileri sürmüştür (Frager ve Fadiman, 1998). Kısaca özetlenecek olursa, Rogers psikolojik sağlamlı üç kategoride ele almıştır: Sağlıklı, bütünleşik benliğe sahip olanlar, nevrotikler ve dağınıklık (disorganization) yaşayanlar.

Makalenin bu kısmında, Bayan E. vakası Rogers'ın Danışan Odaklı Teorisi ile ele alınacaktır.

“Bayan E.'nin babası duygusal olarak mesafeli bir yapıya sahip olduğu, annesi ise beș çocuğun bakımı, ev ve tarla işleriyle uğraşmak zorunda olan bir kadın olduğu için, Bayan E.'nin alması gereken sevgi, yakınlık ve kabulu yeterli derecede alamamış olabileceği düşünülmüştür. Ayrıca, babasının çok katı kurallarının olması, annesinin "Tatsızlık çıkmasın, babanızın dediklerini yapın.” Şeklinde bir tarzının olması ve yaşadığı çevrenin dindar olması sebebiyle etrafındaki nerdeyse herkesin katı kurallara sahip olması sebebiyle Bayan E.'nin koşulsuz olumlu kabulü az miktarda alabilmiş olduğu izlenimi edinilmiştir. Bayan E. yaşadıkları yerde "Kız çocukları sessiz olur. Ev işi yaparlar. Erkeklerin sözünü dinlerler." Gibi kuralların olduğunu, oyun oynamak isterken evde oturmak zorunda kaldığını anlatmış, isteklerini yerine getirmediği zaman babasının kendisini azarladığını eklemiştir. Tüm bu örnekler Bayan E.'nin koşulsuz olumlu kabulü alamamış olduğunu desteklemiştir. Değerli olabilmek için evdeki kurallara uymak zorunda olduğunu öğrenen Bayan E. çocukluğunda değerli olabilmeninin koşulları ile karşılaşmıştır. Koşullara göre davrandığında değerli olduğunu hisseden Bayan E., bu kuralları kendi kuralları gibi benimsemiş ve davranışlarını buna göre şekillendirmiştir. Ayrıca kişinin kendisine olumlu kabul gösterebilmesinin önkoşulu olan başkalarından koşulsuz kabul almayı yaşayamadığı için Bayan E.'nin kendisine karşı da olumlu kabul gösteremediği seanslarda gözlemlenmiştir. En ufak bir hata yaptığında kendisine kızdığı ve üzüldüğü görülmüştür. Bunların yanı sıra, ilişkilerinde diğer kişilere koşulsuz olumlu kabul göstermekte zorlandığı da görülmüştür. Bunun en açık örneği erkek arkadaşı ile olan ilişkisinde karşısına çıkmış, erkek arkadaşının hoşuna gitmeyen yönleri olduğunda çözümü erkek arkadaşından ayrılmakta bulmuş, erkek arkadaşını seviyor olsa da eksik bulduğu yönleri kabul etmekte zorluk yaşamıştır. Kabul edici bir ortamda yetişemeyen Bayan E.'nin özgüven eksikliği yaşıyor olduğu izlenimi de edinilmiştir. Bu bilgiler 1şığında Bayan. E.'nin kendiliği ve deneyimleri arasında uyuşmazlık (incongruence) yaşadığı hipotezi kurulmuştur. 
Örneğin bir seansta Bayan. E.'nin bir arkadaşı ile olan problemi ele alınırken, Bayan. E.'nin kıskançlık duygusunu hissediyor olabilmesi ihtimali üzerinde konuşulduğunda, daha önce bu farkındalığa sahip olmayan Bayan E.'nin kaygılandığı gözlemlenmiştir. Ayrıca ideal benliği ve gerçek benliği arasında büyük farklılık olduğu gözlemlenmiş, Bayan E.'nin bu farklılık sebebiyle birçok olumsuz duygu yaşadığı izlenimi edinilmiştir (Bayan E.'nin yaşadığı uyuşmazlık ve benlik farklılıkları Tory E. Higgins'e ait olan benlik farklı1ıkları teorisi ile daha ayrıntılı olarak ele alındığı için bu noktada ayrıntılı ele alınmayacaktır).

Bayan E.'nin uyuşmazlık (incongruence) sebebiyle yaşadığı olumsuz duygular karşısında savunma mekanizmaları kullandığı farkedilmiştir. Bayan E.'nin Rogers'ın ele aldığı iki önemli mekanizma olan inkar ve çarpıtma mekanizmalarından çarpıtmayı daha sık kullandığı gözlemlenmiştir. Örneğin, kendisini asla kıskanç bir insan olarak tanımlamayan Bayan E.'nin bir arkadaşının kendisine kıskanç olabileceği ile ilgili geri bildirim vermesi üzerine Bayan E.'nin arkadaşının herkese olumsuz geri bildirim veren bir yapısı olduğunu düşündüğü görülmüştür. Diğer bir örnek ise, bir grup içerisinde çoğu zaman lider pozisyonda olmayı hakkettiğini düşünen Bayan E.'nin, bir grupta kendisinden başkası grup başkanı ya da lideri seçildiğinde, kendisi olumlu özelliklerini diğerleri kadar öne çıkarmayı sevmediği için bunu yaşadığını söylemesidir. Bu örneklerde Bayan E.'nin kendilik temsiline uymayan deneyimlerini, bilinç seviyesine alabilmek için bu gerçekliği çarpıtma gereksinimi içerisinde olduğu gözlemlenmiştir.

Üniversiteyi kazanıp, yapı olarak çok farklı bir çevre içerisine girdiğinde, Bayan E.'nin benliğinde değişimler olmaya başladığı gözlemlenmiştir. Aile yaşantısında kabul gören başörtüsü takmas1, erkeklerle yakın olmamas1, sosyal ortamlarda aktif olmaması gibi durumlardan uzaklaştığı, artık bunların kendi benlik temsilinde olmadığı görülmüştür. Rogers'ın önerdiği gibi kendilik temsilinde değişimler yaşamıştır. Bayan E. aynı zamanda ideal benliğinde de değişimler yaşamıştır. Dini kurallara uygun olarak yaşamak Bayan E.'nin önceki ideal benliğindeyken, şu an kendi ahlak davranışlarına uygun davranmanın ideal benliğinde olduğu izlenimi edinilmiştir."

\section{Psikoterapi}

Rogers psikoterapiyi bir uzman tarafindan manipulasyon yapılan ve karşısında daha pasif birinin olduğu bir ortam olarak görmemiştir. Danışanın potensiyel olarak yetkin olan biri olduğunu, terapide ise halihazırda var olan kapasitesinin ortaya çıkarıldığını savunmuştur (Rogers, 1957; aktaran, Frager ve Fadiman, 1998). Ayrıca Rogers, danışanın kendisini neyin üzdügünü, terapide ne yöne doğru gidileceğini, hangi problemlerin daha önemli olduğunu, hangi yaşantıların problemlerin altında yattığını en iyi bilen kişi olduğuna inanmıştır (Rogers, 1961). Bu sebeple terapi sürecinde danışanın ilerleme yönüne göre hareket etmenin en iyi yöntem olduğu sonucuna varmıştır (Rogers, 1961; Friedman ve Schustack, 2012). Rogers terapiye gelen bireylere hasta demek yerine danışan demeyi tercih etmiştir.Çünkü, danışanların yardıma ihtiyacı olan, bunu tek başına başaramamış, ancak kendi durumlarını anlayabilecek kapasiteye sahip bireyler olduğuna inanmıştır (Frager ve Fadiman, 1998). Eğer belirli özelliklere sahip bir ilişki sağlanabilirse, danışanın o ilişki içerisinde değişim ve büyüme için kapasiteyi bulabileceğini söylemiştir (Rogers, 1961).

Rogers olumlu yönde kişilik değişiminin başlayabilmesi ve devam edebilmesi için gerekli ve yeterli olan altı koşuldan bahsetmiştir (1957). İlk koşul terapi ortamında iki kişinin psikolojik bir temas halinde olmasıdır. Bu koşulun karşılanabilmesi için kişilerin temas halinde olduklarını farkındalık düzeyinde algılamaları gerekmektedir (Monte ve Sollod, 2003). Rogers'a göre bazen sadece bir terapistin ya da yardım veren pozisyonda olan kişinin, orada, o kişi için bulunmasının bile iyileştirici etkisinin olduğunu belirtmiştir (Cervone ve Pervin, 2008). İkinci koşul, danışanın uyuşmazlık, hassaslık ya da kaygı yaşıor halde, yani devam eden bir problem yaşıyor olması 
gereğidir (Rogers, 1957). Üçüncü koşul, terapistin ilişkide gerçek, samimi, entegre olması gereğidir (Rogers, 1961). Samimi bir terapist olarak kendi duygularının farkında olmalı, duygularını inkar etmeden farkındalık düzeyinde tutabilmelidir. Eğer danışana karşı olumsuz duygular hisseder ve bu duygular terapinin olumlu gidişatının önünde duran bir hale gelirse, terapist danışanla, bir meslektaşı ya da süpervizörü ile bu duyguları konuşabilir (Rogers, 1957). Terapistin gerçek, entegre ve bütün olması gereği kuralına bakıldığında, terapistin hayatının tüm alanlarında kendini gerçekleştirmiş bir birey kadar mükemmel olmasına gerek yoktur. Terapi saatinde samimi bir şekilde kendisi olabilen bir terapist olması, koşulun sağlanması için yeterlidir (Rogers, 1957). Uyumlu ve içten bir terapist ile danışan resmi bir ilişkidense gerçek bir ilişki içerisinde olacaktır (Cervone ve Pervin, 2008; Friedman ve Schustack, 2012). Diğer koşul, terapistin danışana karşı koşulsuz olumlu kabul gösterebilmesidir.Rogers, sıcak, kabul edici ve yakın bir ilişkinin danışanın faydasına olacak bir ilişki olduğunu öne sürmüştür (Rogers, 1957). Eğer terapist davranışları, düşünceleri, durumu ne olursa olsun danışanı kabul edebilir, sevebilir ve sayg1 gösterebilirse koşulsuz olumlu kabul göstermiş olacaktır. Yakın ve kabul gördügü bir ilişki içinde olması, danışanın değerin koşulları ile karşılaşmadan, güvenli, sevilebilir, değer verilen bir ilişki içerisinde hissetmesini sağlayacak ve bu durum terapi ilişkisinin faydası açısından oldukça önemli bir faktör olacaktır (Rogers, 1961). Beşinci koşul, terapistin empatik anlamayı gerçekleştirebilmesi ve danışan ile danışanın dünyası içerisinde iletişim kurabilmesidir. Diğer bir deyişle, terapist danışanın yaşantılarını, danışan tarafından yaşandığı şekilde algılayabilmelidir (Rogers, 1957; Cervone ve Pervin, 2008). Rogers tarafından sıklıkla kullanılan duyguların yansitılması tekniği, empatinin seansta yaşanabilmesi için önemli bir tekniktir (Monte ve Sollod, 2003). Terapist duyguları yansıtırken bir yandan danışanın farkındalık kazanmasını ve duygularını anlayabilmesini sağlayacak, diğer yandan da danışanın dünyası içerisinde iletişim kurduğunu danışana hissettirecektir (Monte ve Sollod, 2003; Friedman ve Schustack, 2012). Rogers empatinin faydalı ve gerekli olduğunu çünkü danışanın kendisini dinleyebilmesini, ve kendi terapisti olabilmesini sağladığını vurgulamıştır (Feist ve Feist, 2008; Friedman ve Schustack, 2012). Rogers empatinin, kabul ile aynı şey olmadığını, empatinin danışanın gözleri ile görmek olduğunu belirtmiştir (Rogers, 1961). Ayrıca empatinin, sempati ile karıştırılmaması gereğini eklemiştir. Sempatinin danışana karşı bir his olduğunu, terapistin değerlendirmesi sonucu ortaya çıktığını ve terapötik olmadığını belirtmiştir (Feist ve Feist, 2008). Son koşul ise terapistin empatik olmasının ve koşulsuz kabul göstermesinin başarılabilmesi ve de danışanın bu kabul ve empatiyi algilayabilmesidir (Rogers, 1957).

Rogers ilk koşul dışında diğer koşulların sürekli değişkenler olduğunu, koşullar ne kadar gerçekleştirilebilir ise terapinin sonucunun kişilik değişimi açısından o kadar olumlu olacağını önermiştir (Rogers, 1957). Rogers ayrıca bu koşulların herhangi bir ilişki içerisinde gerçekleşmesi durumunda değişimin gerçekleşeceğini, ancak terapistin ilgili konulara dair bilgi birikimi sebebiyle terapist-danışan ilişkisi içerisinde değişimin diğer ilişkilerde olduğundan daha çok olacağını inanmıştır (Rogers, 1961).

Rogers terapötik değişim sırasında danışanların geçtiği yedi aşamadan bahsetmiştir. Bu aşamalar danışanın en savunmacı olduğu halinden en entegre haline doğru sıralanmıştır (Feist ve Feist, 2008). İlk aşamada danışan değişim için herhangi bir ihtiyacı olduğunun farkında değildir. $\mathrm{Bu}$ aşamadayken kişiler genellikle terapiye gelmezler, ancak böyle bir kişi terapide ise dişsal sebepler ile orada bulunacaktır. Bu aşamada danışan son derece katı ve dirençlidir. İkinci aşamada danışan daha az katı hale gelmiştir ancak problemin kendisinde değil, başkalarında olduğuna inanmaktadır. Bu aşamada danışan duygularını anlamada başarısızdır. Danışan üçüncü aşamaya geldiğinde benliği hakkında daha fazla konuşabilmeye başlamış ancak bunu sanki bir nesneden bahsediyormuşcasına yapmaktadır. Şimdiki zamandaki duygularını sahiplenme konusunda halen başarısız olsa da geçmiş ve gelecekteki duygularından bahsedebilir hale gelmiştir. Bu aşamada 
danışan çoğu kararında ve davranışındaki kişisel sorumluluğunu kabul etmede zorluk yaşamaktadır (Monte ve Sollod, 2003; Feist ve Feist, 2008). Dördüncü aşama duyguların kısmi olarak tanındığı evredir. Danışan bu aşamada duygular hakkında konuşabilir ancak şimdiki zamanki duyguları ile ilgili halen sıkıntı yaşamaktadır. Eğer şimdiki zamanda bir duygu ifadesinde bulunursa bu yaşantısını inkar ya da çarpıtma savunma mekanizması ile farkındalığa çıkarmayabilir. Bu aşamada danışan içe atmış olduğu başkasının değerlerini sorgulamaya ve benliği ile deneyimleri arasında yaşadığı farklılığı algılamaya başlamıştır. Ayrıca bu aşamada danışan daha çok sorumluluk olmaya başlamıştır. Beşinci aşama değişim ve büyümenin hissedilmeye başlandığı aşamadır. Danışan "gerçek ben” olabilmek için istek duymaya başlamış ve kendi içsel değerlendirmelerine değer vermeye başlamıştır. Danışan kendi kararlarını verebilmeye ve daha çok sorumluluk alabilmeye başlamıştır (Monte ve Sollod, 2003; Feist ve Feist, 2008). Altıncı aşama belirgin bir şekilde büyümenin görüldüğü, kendini gerçekleştirmeye doğru alınan yolun artık geri döndürülemez olduğu aşamadır. Danışan, deneyimlerinin inkar ve çarpıtmaya uğramadan farkındalık düzeyine çıkmasını rahatça kabul edebilir düzeye gelmiştir. Daha uyumlu, duygularına açık ve kendi benliğine güvenebilir haldedir. Ayrıca, kendisine koşulsuz olumlu kabul gösterebilecek duruma gelmiştir. Terapi eğer bu aşamada sonlandırılırsa, danışan bir sonraki aşamaya kendisi de geçebilir çünkü bahsedildiği üzere değişim artık geri döndürülemez derecededir. Son aşamada danışan artık tamamıyla işlevsel (fully functioning) hale gelmiştir. Danışan terapideki kazanımlarını tamamıyla günlük yaşantısına genelleyebilir durumdadır. Bu aşamada benlik tamamen entegre, esnek, güvenilir ve değişebilme kapasitesine sahip haldedir (Monte ve Sollod, 2003; Feist ve Feist, 2008).

Rogers, terapi eğer tamamen başarılı bir şekilde tamamlanırsa, tamamen işlevsel kişinin oluşacağını önermiştir (Rogers, 1961). Rogers tamamen başarılı bir terapi süreci ardından, kişinin daha uyumlu, daha az savunma kullanan, deneyime daha açık ve daha uyumlu (adaptive) biri olacağını söylemiştir (Feist ve Feist, 2008). Danışanın olumlu kendini kabulu gerçekleştirebildiği gibi ilişkilerinde de daha kabul edici olabileceğini belirtmiştir. Ayrıca kişinin dünyayı algılayışının daha realistik olacağını, ideal benliği ile gerçek benliği arasındaki farkın azalacağını öne sürmüştür. Bununla birlikte danışanın daha az hassas ve kaygılı olacağını, deneyimlerinin sorumluluğunu alabileceğini söylemiştir. Son olarak Rogers, danışanın kendi deneyimlerine güvenebilmeye başlayacağını ve diğerlerinin farklı olduğu gerçeğini kabulleneceğini eklemiştir (Rogers, 1957; 1961; Friedman ve Schustack, 2012).

Makalenin son kısmında kendilik farklılığı yaşayan Bayan E. vakası Rogers'ın danışan odaklı terapisi ile ele alınacaktır.

"Daha önce bahsedildiği üzere Bayan E., farklı benlik temsilleri arasında büyük farklılıklar yaşamaktadır. Higgins, benlik farklılıkları yaşayan danışanlar ile yapılan terapide hedeflerin, gerçek/kendi benlik temsilinin değiştirilerek benlik rehberi (self-guide) temsilleri ile daha az farklılığı olması, benlik rehberi temsillerinin değiştirilerek gerçek/kendisi temsili ile farklılığın azaltılması ya da kişinin bu farklılıklara maruz kalmasının azaltılması şeklinde olabileceğini önermiştir (1987). Gerçek değişimi getireceği düşünülmediği için farklılıklara maruz kalmasının azaltılması hedefinin dışındaki hedefler Bayan E. ile yapılan terapide danışan odaklı terapi yaklaşımı ile çalışılmıştır.

Bayan E. ile görüşmelere ilk başlandığında danışanın, Rogers'ın önerdiği terapötik değişim aşamalarından ikincisinde olduğu gözlemlenmiştir. Bayan E.'nin problemlerde genel olarak sorumluluğun başkalarına ait olduğunu düşündüğü, kendi üzerine sorumluluk alamadığı gözlemlenmiştir. Ayrıca duyguları ile ilgili farkındalık düzeyinin oldukça düşük olduğu sonucuna varılmıştır.

Bayan E. Rogers'ın da belirttiği gibi daha ilk görüşmede neye ihtiyacı olduğunu, terapinin nasıl şekillenmesi gerektiğini ve kendisine neyin iyi geleceğini bildiğini göstermiştir. Bayan E. 
"Ciddi bir ilişki olmasını değil, yakın bir ilişki olmasını, bir abla gibi bana görmekte zorlandığım şeyleri görebilmem için yardımcı olmanızı istiyorum" talebini belirtmiştir. Ancak "bir abla gibi" kalıbı terapistin kendi ideal/kendisi benliği ile çatışmış, "iyi terapist" olma ihtiyacı ile danışanın bu ihtiyacını çok iyi göremediği düşünülmüştür. Kendi "iyi terapist” imajına göre görüşmelere devam eden terapist, yaklaşık dört görüşme sonra, Bayan E.'nin ihtiyaçlarını tekrar dile getirmesi ile karşılaşmıştır. Bayan E. terapiste "Bazen beni sadece teori gibi gördüğünüzü, beni anlamaya çalışmadığınızı düşünüyorum ve beni anlamanıza ihtiyacım var” geribildirimini vermiştir. Bu geribildirim terapist için oldukça değerli bir geri bildirim olmuş, "iyi terapist" olma çabası gösterirken aslında ideal benliğin kendisini ketlediğini, amacını gerçekleştirememesine sebep olduğunu görmüştür. Bu görüşmenin ardından artık terapist Bayan E. ile görüşmelerini danışanı anlamaya odaklı, onunla empati kurabildiği, gerçek bir ilişki olarak devam ettirmiştir.

Yukarıda bahsedildiği üzere, Rogers kişilik değişminin gerçekleşebilmesi için gerekli ve yeterli olan altı koşuldan bahsetmiştir (1957). Bu koşullar Bayan E. ile olan terapi sürecinde ele alınacaktır. İlk koşul Bayan E.'nin terapiye başvurması ve farkındalık seviyesinde terapist ile ilişki içerisinde olduğunu bilmesi sebebiyle karşılanmıştır. İkinci koşul, Bayan E.'nin bir çok benlik temsili arasında farklılık yaşıyor olması, hassas olması ve farklılık yaşadığı durumlarda kaygı yaşıyor olması sebebiyle karşılanmıştır. Üçüncü koşul terapistin terapide uyumu (congruent), entegre ve samimi olması gereğidir. Bayan E.'nin gerçek bir ilişki isteğini ikinci kez terapistle paylaşmasının ardından terapist bu durumu anlamış ve Bayan E. ile duygularını yaşayabildiği, gerektiğinde bunları Bayan E. ile veya süpervizyon ortamında paylaşabildiği bir ilişki kurmuştur. Örnek vermek gerekirse, Bayan E.'nin yaşadığı benlik farklılıkları sebebiyle sürekli karar değiştiren yapısı, terapistin bazen öfkelenmesine sebep olabilmiş, bunu farkedip süpervizyon ortamında paylaşmıştır. Terapist hayatının her alanında uyumlu ve entegre bir benliğe sahip olduğunu iddia etmemekte, ancak Bayan E. ile olan seanslarında, bunu başarabildiğini, Bayan E.'ye uyumlu benliği modelleyebildiğini düşünmüştür. Diğer koşul terapistin danışana karş1 koşulsuz olumlu kabul gösterebilmesidir. Terapist danışana karşı koşulsuz olumlu kabul göstermekte zorlanmamış, danışana karşı yakın hissedebilmiştir. Danışan ne yaparsa, ne derse, ne hissederse hissetsin onu olduğu şekilde kabul edebildiğini düşünmüştür. Terapistin kendi erken dönem yaşantılarında koşulsuz olumlu kabulü tam olarak alabildiğini düşünmemesi, danışana bunu tam olarak verebiliyor olması konusunda soru işareti doğursa da terapi sürecinde bu konuda bir problem yaşanmamıştır. Bayan E. seanslarda bir kaç kez "Sizin ne olursa olsun beni kabul edeceğinizi, yargılamayacağınızı biliyorum” ifadesini kullanmıştır. Bu ifadesi, bu koşulun sağlanmış olduğunu düşündürmüştür. Danışanın, terapi ilişkisi içersinde güven, kabul ve sıcaklığı yaşadıkça bunu hayatındaki diğer ilişkilere de genellemeye başlayabildiği, çevresindekilere ve kendisine koşulsuz kabul gösterebilmeye başladığı gözlemlenmiştir. Rogers beşinci koşulun terapistin danışan ile empati kurabilmesi, onun dünyası içerisinde iletişim kurabilmesi olduğunu belirtmiştir (Rogers, 1957). Terapist sürecin başlarında bunu yapamamış ancak danışandan aldığı geri bildirim ile danışan ile empati kurabilmek için çabalamaya başlamıştır. Sürecin ileriki kısımlarında artık terapist danışanın dünyasını anlayabildiğini, o dünyanın içerisine girebildiğini ve danışanla bu dünya içerisinde iletişim kurabildiğini düşünmektedir. Son koşul, danışanın terapistten gördüğü kabul ve empatiyi algılayabildiği düşünüldüğü için karşılanmıştır.

Bahsedilen koşulların ve Rogers'ın terapisinde önemli bir yer tutan duyguların yansıtılması tekniği de kullanılarak şu an Bayan E. ile sürecin sonlarına yaklaşılmıştır. Bayan E. süreç içerisinde ailesinin değerlerini aldığını, fakat bunların kendi benliğinden gelmediğini anlamıştır. Bu sebeple Bayan E. zaruri benlik/başkası kendilik temsilini değiştirebilmiş, artık ailesinin yanına giderken eskiden olduğu kadar çok kaygı ve utanç duymadığını belirtmiştir. Zaruri/kendisi ile gerçek benlik/kendisi arasındaki farkın da azaldığı gözlemlenmiş, Bayan E.'nin zaruri benlik/kendisi temsilini yumuşatabildiği, eskisi kadar suçluluk duymadığı gözlemlenmiştir. 
Özellikle artık erkek arkadaşından sık sık ayrılmayı bırakmış, onunla yakınlaştığında aldığı hazzı kabul edebilmiştir. Son olarak ideal/kendisi benlik temsili ile gerçek benlik arasındaki farkın da azaldığı gözlemlenmiştir. Bayan E. artık gerçek benliğini kabul edebilir, yapamadığı şeylerde kendisine anlayış gösterebilir bir duruma gelmiştir. Ancak kendisini geliştirme yönündedeki motivasyonunu kaybetmemiştir. Bayan E.'nin şu an Rogers'ın belirttiği değişim aşamalarından aşama beş ve altının özelliklerini birlikte gösterdiği görülmüştür. Artık "gerçek ben” olabilmek için isteği olduğu ve kendi değerlendirmelerine güvendiği görülmüştür. Kararlarını vermede eskisi gibi problem yaşamadığı ve daha çok sorumluluk alabildiği gözlemlenmiştir. Ender de olsa bazı durumlarda sorumluluğu alamadığı da gözlemlenmiştir. Savunma mekanizmalarına eskisine göre daha az başvurması bir diğer önemli kazanımıdır. En önemli olarak görülen değişim Bayan E.'nin kendisine ve ilişkilerinde koşulsuz olumlu kabul gösterebilmesi olmuştur. Son olarak Bayan E. terapideki kazanımlarını günlük yaşantısına genelleyebilir hale gelmiştir.

Poyrazlı, makalesinde Türk kültürünün ataerkil ve otoriter bir kültür olduğunu, Türkiye’de danışanların daha çok yönlendirmeye ihtiyaç duyabileceklerini, bu sebeple danışan odaklı terapinin yönlendirici olmayan özelliğinin Türk kültürüne uymayabileceğini vurgulamıştır. Bu durum göz önünde bulundurarak, terapistlerin bu kültüre hassas olarak davranmaları gerektiğini belirtmiştir (2003). Bayan E. ile olan görüşmelerde Bayan E.'nin yönlendirme talepleri olmuştur. Bu taleplerin Bayan E.'nin kendi benliğini oluşturmakta yaşadığı zorluklar sebebiyle terapistten onay alma olarak ortaya çıktığı düşünülmüş ve seanslarda danışan ile birlikte ele alınmıştır. Bayan E.'nin bu konu üzerinde çalışılmasının ardından kendi değerlendirmelerine dayanarak, sorumluluğu alıp kararlar verebildiği görülmüştür. Türk kültüründe danışanlar terapinin yönlendirici olmasını istiyorlar ise de bu durumun danışanın bireysel özellikleri göz önünde bulundurularak ele alınabildiği ve terapide herhangi bir sorun teşkil etmediği Bayan E. ile olan seanslarda gözlemlenmiştir.

Son olarak, hümanistik psikoloji, teorisyenin kendi değerleri ve ihtiyaçlarını göz önünde bulundurarak teori oluştuyor olması yönünden eleştirilmektedir (Monte ve Sollod, 2003). Bu sebeple hümanistik teorilerin genellenebilir olup olmaması tartışılmaktadır. Bayan E. ile olan süreçte Rogers'ın teori ve terapisinin etkili olduğu görülmüştür. Ancak, Rogers ve Bayan E.'nin hayatlarında ciddi benzerliklerin olduğu dikkat çekmiştir. İkisinin de son derece sınırlayıcı ve dindar ailelerden geldikleri, koşulsuz kabul göremediklerini, kendilerini gerçekleştirebilmeleri önünde ailenin destekleyici rolünün olmadığı görülmüştür. Ayrıca ikisinin de yaşamlarının bir yerine kadar bu dini motivasyonla hayatlarına devam ettikleri ve ardından dini motivasyondan uzaklaştıkları görülmüştür. Bu özellikler dikkate alındığında, Rogers'ın ihtiyacı olan şeylerin Bayan E.'nin de ihtiyaçlarına denk gelmesi normal görünmekte, ancak başka ihtiyaçları olabilecek bir danışan ile sürecin nasıl işleyeceği farklı danışanlar ile çalışılarak gözlemlenmelidir. 


\section{Kaynaklar}

Barnett, M., D. ve Womack, P., M. (2015). Fearing, not loving, the reflection: Narcissism, self-esteem, and self-discrepancy theory. Personality and Individual Differences, 74, 280-284. Burger, J., M. (2011). Personality (8th ed.). California: Wadsworth.

Cervone, D., ve Pervin, L., A. (2008). Personality: Theory and Research (10th ed.). Danvers, MA, United States: John Wiley ve Sons, Inc.

Feist, J., ve Feist, G., J. (2009). Theories of Personality (7th ed.). United States of America: McGraw-Hill.

Frager, R., ve Fadiman, J. (1998). Personality and Personal Growth (4th ed.). United States: Longman.

Friedman, H., S. ve Schustack, M.i W. (2012). Personality: Classic Theories and Modern Research (5th ed.). Boston, MA : Allyn ve Bacon.

Geiwitz, P., J. (1969). Non-Freudian Personality Theories: Basic Concepts in Psychology Series. California: Brooks/Cole.

Higgins, E., T. (1987). Self-Discrepancy: A theory relating self and affect. Psychological Review, 94(3), 319-340.

Monte, C., F. ve Sollod, R., N. (2003). Beneath The Mask: An Introduction to Theories of Personality. Danvers, MA, United States: John Wiley ve Sons, Inc.

Poyrazli, S. (2003). Validity of Rogerian Therapy in Turkish culture: A cross-cultural perspective. Journal of Humanistic Counseling, Education and Development, 42, 107-115. Rogers, C., R. (1957). The necessary and sufficient conditions of therapeutic change. Journal of Consulting Psychology, 21, 95-103.

Rogers, C., R. (1961). On becoming a person. Boston: Houghton Mifflin.

Schultz, D., P. ve Schultz, S., E. (2005). Theories of Personality (8th ed.). California:

Thomson Wadsworth.

Stevens, M., J. (1992). Prescott Lecky: Pioneer in consistency theory and cognitive therapy. Journal of Clinical Psychology, 48(6), 807-811.

Stevens, E., N., Lovejoy, M., C. ve Pittman, L., D. (2014). Understanding the relationship between actual: ideal discrepancies and depressive symptoms: A developmental examination. Journal of Adolescence, 37, 612-621.

Strauman, T., J. ve Higgins, E., T. (1988). Self-Discrepancies as predictors of vulnerability to distinct syndromes of chronic emotional distress. Journal of Personality, 56(4), 685-

707. 


\section{Summary: \\ A review of treatment of self discrepancy with Carl Rogers' client centered therapy: An illustration of a case}

Self Discrepancy between different selves has long been the issue of the discipline of psychology. Theories generally, including Carl Rogers', mention that people experience discrepancy between actual self and ideal self. In addition, people who are experiencing discrepancy between actual and ideal selves, they experience negative emotions. Tory E. Higgins proposed that there are three different domains of self, which are actual, ideal and ought selves. In addition, he added the standpoint to these selves as from own self and others'. According to Higgins, people experience different kinds of negative emotions as dejection related emotions like dissatisfaction, disappointment and sadness, or agitation related emotions like fear, threat and edginess when they experience different kinds of discrepancies. Rogers proposed that people experience this discreapancy because of conditions of worth they encountered in childhood and they try to cope with these negative emotions with the help of defensive processes. Rogers claimed that the development of self is not limited to childhood years, so in therapy if the client experiences a relationship which is congruent, genuine, empathic and has unconditional positive regard, the client can narrow the gap between the different selves and strive towards self actualization. In this paper, self discrepancy from the Higgins' point of view and Rogerian client centered therapy is reviewed. In addition, a case who experiences self discrepancy was approached with the Rogerian client centered therapy.

Keywords: Self discrepancy, Carl Rogers, Client Centered Therapy. 